\title{
Role of VEGF signalling in the regulation of KDR expression in endothelial and tumoral microenvironment
}

\author{
Jacinta Serpa ${ }^{1,2,3^{*}}$, Cheila Torre ${ }^{1,2,3}$, Francisco Caiado ${ }^{1,2,3}$, Sérgio Dias ${ }^{1,2,3}$ \\ From 16th International Charles Heidelberger Symposium on Cancer Research \\ Coimbra, Portugal. 26-28 September 2010
}

Vascular endothelial growth factor (VEGF) is the main regulator of angiogenesis. The paracrine VEGF signalling through KDR consists on the action of VEGF produced by a cell from different origins on KDR that is displayed on endothelial cells surface. In cancer, the functional significance of VEGF in tumour angiogenesis is very well documented but in the last 10 years a functional VEGF:KDR autocrine loop have been described in solid and haematological tumours, favouring disease burden by cell proliferation and motility promotion. However the regulation of KDR expression in endothelial and tumour cells remains rather unclear. The aim of the study is to evaluate the role of VEGF signalling in the expression of KDR in endothelial and tumour cells. This study was developed in endothelial cells (BEnd3, HUVEC and EPCs) and in colorectal carcinoma cell line HCT15. The regulation of KDR promoter was performed by Fire-fly luciferase reporter gene assays, using pGL3Basic deletion constructs of KDR promoter. The expression of KDR was analysed by FACS and immunofluorescence. The involvement of KDR in its own expression was confirmed using a neutralising anti-KDR. We observed that VEGF stimulates the activity of KDR promoter through KDR itself, in BEnd3, HUVEC, EPCs and HCT15; and through FLT1 in HUVEC. The results of promoter activity correlate with the concomitant expression of KDR. We can conclude that VEGF signalling pathway regulates the expression of VEGF receptor 2, KDR.

\footnotetext{
* Correspondence: jacinta.serpa@gmail.com

'Centro de Investigação de Patobiologia Molecular, Instituto Português de Oncologia de Lisboa Francisco Gentil, EPE, Lisboa, Portugal

Full list of author information is available at the end of the article
}

\section{Author details}

${ }^{1}$ Centro de Investigação de Patobiologia Molecular, Instituto Português de Oncologia de Lisboa Francisco Gentil, EPE, Lisboa, Portugal. ${ }^{2}$ Instituto Gulbenkian de Ciência, Oeiras, Portugal. ${ }^{3}$ Centro de Estudos de Doenças Crónicas, Faculdade de Ciências Médicas, Universidade Nova de Lisboa, Lisboa, Portugal.

Published: 24 September 2010

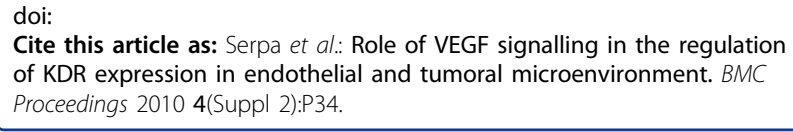

Cite this article as: Serpa et al: Role of VEGF signalling in the regulation of KDR expression in endothelial and tumoral microenvironment. BMC Proceedings 2010 4(Suppl 2):P34.

Submit your next manuscript to BioMed Central and take full advantage of:

- Convenient online submission

- Thorough peer review

- No space constraints or color figure charges

- Immediate publication on acceptance

- Inclusion in PubMed, CAS, Scopus and Google Scholar

- Research which is freely available for redistribution

Submit your manuscript at www.biomedcentral.com/submit
C Biomed Central 